\title{
Comparative Study on Professional Identity of Undergraduate Nursing Students with Different Admission Levels before Clinical Practice
}

\author{
Liping Li, Rui Sun \\ Medical College of Yangtze University, Jingzhou, China \\ Email: 108940016@qq.com
}

How to cite this paper: Li, L. P., \& Sun, R. (2021). Comparative Study on Professional Identity of Undergraduate Nursing Students with Different Admission Levels before Clinical Practice. Open Journal of Social Sciences, 9, 59-66.

https://doi.org/10.4236/jss.2021.911005

Received: April 19, 2020

Accepted: November 7, 2021

Published: November 10, 2021

Copyright $\odot 2021$ by author(s) and Scientific Research Publishing Inc. This work is licensed under the Creative Commons Attribution International License (CC BY 4.0).

http://creativecommons.org/licenses/by/4.0/

\begin{abstract}
Objective: To investigate the status of professional identity of undergraduate nursing students at different admission levels before clinical practice, and analyze the differences and reasons, so as to provide basis for guiding the development of nursing students' professional identity. Methods: A total of 186 nursing students (including the first batch of admissions from senior middle school, the second batch admissions from senior middle school of secondary college, and the admissions from junior college graduates) were surveyed by using occupational identity scale before clinical practice. The scale contains four dimensions: career moratorium, career diffusion, career achievement, and career foreclosure. The highest-scoring dimension is recorded as the status type of professional identity for each nursing student. If a student's highest score is not unique, his type is considered ambiguous. Results: 1) $35.5 \%$ of them are in the status of career moratorium, $1.6 \%$ of them are in the status of career diffusion, $52.2 \%$ of them reach to the status of career achievement, $2.2 \%$ of them are in the status of career foreclosure, $8.6 \%$ of them are ambiguous. 2) The ANOVA analysis and further LSD-test of four dimensions of the three categories of nursing students found that only the difference in the career achievement dimension is statistically significant $(P<0.05)$, the second batch of admitted nursing students from senior middle school had the highest score, followed by the nursing students admitted from junior college graduates, and the first batch of admitted nursing students from senior middle school has the lowest score, the remaining differences are not statistically significant $(P>0.05)$. Conclusions: Nearly half of the undergraduate nursing students have not reached the career achievement. The second batch of admitted nursing students has the highest professional achievement, and the first batch has the lowest. Nursing educators should take targeted measures to guide the nursing students to the state of career achievement and improve the
\end{abstract}


professional identity level.

\section{Keywords}

Undergraduate Nursing Students, Clinical Practice, Professional Identity

\section{Introduction}

Clinical practice is an important part of nursing education, a process of applying the theoretical knowledge learned in the previous period to practice, and an important adaptation stage of transition to nurse role. A fundamental goal of medical education is supporting learners in forming a professional identity (Sternszus, Boudreau, Cruess et al., 2020), so developing professional identity is an essential transition for nursing students as they move through their undergraduate degree. And as part of the core competency development of nursing students, professional identity has been included in the standard of nursing professional certification. Professional identity is described as a persons' perception of themselves within a profession or the collective identity of the profession (Browne, Wall, Batt, \& Bennett, 2018). Undergraduate education is currently the main body of training nursing talents in china, In the short run, Only if undergraduate nursing students recognize the nursing profession, they will make efforts in the internship process and achieve the college's nursing talent training goals; In the long run, whether they recognize the nursing major affects whether they will pursue a career as a nurse in the future. Nursing shortages and student nurse retention generally is an international concern (Green, 2018). Therefore, the research on professional identity of undergraduate nursing students is very important. Existing Chinese researches on nursing student's professional identity, the research tools mostly use professional identity questionnaires specifically for nursing students to explore the level of nursing students' professional identity. This study uses a special occupational identity scale to explore the type of professional identity of undergraduate nursing students before clinical internship and the differences in professional identity development of undergraduate nursing students at different levels of admission, and analyze the current situation and the reasons for the differences, and provide a basis for the guidance of the professional identity development of nursing students at school.

\section{Research Objects and Methods}

\subsection{Research Objects}

Our university is a first-class undergraduate university with a second-level college. Our students have been employed in hospitals at all levels in and outside the province. Targeted at our school's 186 undergraduate nursing students who are going to practice, 22 males and 164 females. Among them, 71 are the first batch of admissions from high school, 74 are the second batch of admissions 
from high school of secondary college, and 41 are the admissions from junior college graduate.

\subsection{Research Tools}

Revised version of Chinese scholars based on the "Occupational Identity Scale" compiled by Melgosa (Melgosa, 1987), has been proved to be suitable for measuring the professional identity of college students in China. The scale is divided into 4 dimensions: career moratorium, career diffusion, career achievement, and career foreclosure, of which career achievement is the most ideal type. Each dimension contains 7 entries, each entry has two answers "yes" and "no", "yes" score 1 point, "no" score 0 point. Based on the dimension with the highest score among the four dimensions, it was recorded as the current professional identity type of the respondents. The retest reliability of the four dimensions of the scale was calculated in this study, all of which were between 0.712 and 0.830 .

\subsection{Investigation Method}

A 42-person class was selected for pre-survey, and a paper survey was formally conducted on all students two weeks later. The questionnaire was withdrawn on the spot. 190 questionnaires were issued and 186 valid questionnaires were recovered, with an effective recovery rate of $97.9 \%$.

\subsection{Data Analysis}

SPSS 20.0 was used to enter data and carry out statistical analysis. The proportion of nursing students in each professional identity type is expressed as a percentage, and One-way ANOVA was used to compare the differences in professional identity of nursing students at different admission levels.

\section{Results}

\subsection{Percentage of Professional Identity Types of Nursing Students at Different Admission Levels}

Among the four dimensions, the one with the highest score is considered the type of professional identity of nursing students. 186 nursing students, of which $66(35.5 \%)$ are career moratorium type, $3(1.6 \%)$ are career diffusion type, 97 $(52.2 \%)$ are career achievement type, $4(2.2 \%)$ are career foreclosure type, 16 (8.6\%) are currently ambiguous about the type of professional identity, that is, the highest score is not unique. See Table 1 for details.

\subsection{ANOVA of Professional Identity Types of Nursing Students at Different Admission Levels}

The comparison of the scores of the three categories of nursing students in each dimension shows that only the difference in the career achievement dimension is statistically significant $(\mathrm{P}=0)$. See Table 2 for details. Further LSD comparison 
Table 1. Statistics of occupational identity types at different admission levels $\mathrm{n}(\%)$.

\begin{tabular}{ccccccc}
\hline & $\begin{array}{c}\text { Career } \\
\text { moratorium }\end{array}$ & $\begin{array}{c}\text { Career } \\
\text { diffusion }\end{array}$ & $\begin{array}{c}\text { Career } \\
\text { achievement }\end{array}$ & $\begin{array}{c}\text { Career } \\
\text { foreclosure }\end{array}$ & unclear & total \\
\hline $\begin{array}{c}\text { The first } \\
\text { batch }\end{array}$ & $31(43.7)$ & $2(2.8)$ & $29(40.8)$ & $1(1.4)$ & $8(11.3)$ & $71(100)$ \\
$\begin{array}{c}\text { From senior } \\
\text { college }\end{array}$ & $14(34.1)$ & $0(0)$ & $18(43.9)$ & $3(7.3)$ & $6(14.6)$ & $41(100)$ \\
$\begin{array}{c}\text { The second } \\
\text { batch }\end{array}$ & $21(28.4)$ & $1(1.4)$ & $50(67.6)$ & $0(0)$ & $2(2.7)$ & $74(100)$ \\
total & $66(35.5)$ & $3(1.6)$ & $97(52.2)$ & $4(2.2)$ & $16(8.6)$ & $186(100)$ \\
\hline
\end{tabular}

Table 2. Comparison of various types of professional identity of nursing students at different admission levels.

\begin{tabular}{|c|c|c|c|c|c|c|}
\hline & & $\mathrm{N}$ & $\bar{x} \pm s$ & $\begin{array}{l}\text { Standard } \\
\text { error }\end{array}$ & $\mathrm{F}$ & $P$ \\
\hline \multirow{3}{*}{$\begin{array}{c}\text { Career } \\
\text { moratorium }\end{array}$} & The first batch & 71 & $3.93 \pm 1.589$ & 0.189 & 0.349 & 0.706 \\
\hline & From senior college & 41 & $3.76 \pm 1.445$ & 0.226 & & \\
\hline & The second batch & 74 & $3.73 \pm 1.492$ & 0.173 & & \\
\hline \multirow{3}{*}{$\begin{array}{c}\text { Career } \\
\text { diffusion }\end{array}$} & The first batch & 71 & $1.69 \pm 1.214$ & 0.144 & 2.679 & 0.071 \\
\hline & From senior college & 41 & $1.17 \pm 1.093$ & 0.171 & & \\
\hline & The second batch & 74 & $1.50 \pm 1.101$ & 0.128 & & \\
\hline \multirow{3}{*}{$\begin{array}{c}\text { Career } \\
\text { achievement }\end{array}$} & The first batch & 71 & $3.37 \pm 1.466$ & 0.174 & 13.244 & 0.000 \\
\hline & From senior college & 41 & $4.05 \pm 1.897$ & 0.296 & & \\
\hline & The second batch & 74 & $4.82 \pm 1.808$ & 0.210 & & \\
\hline \multirow{3}{*}{$\begin{array}{c}\text { Career } \\
\text { foreclosure }\end{array}$} & The first batch & 71 & $1.54 \pm 1.106$ & 0.131 & 2.791 & 0.064 \\
\hline & From senior college & 41 & $2.12 \pm 1.720$ & 0.269 & & \\
\hline & The second batch & 74 & $1.97 \pm 1.489$ & 0.173 & & \\
\hline
\end{tabular}

of the career achievement dimension, the score of the undergraduate nursing students enrolled in the second batch are higher than those of the undergraduate nursing students admitted from junior college, the score of the undergraduate nursing students admitted from junior college are higher than those of the undergraduate nursing student enrolled in the first batch, the difference is statistically significant $(P<0.05)$, See Table 3 for details. Judging from the $P$ value of the two-step comparison, the probability class I errors was not increased.

\section{Discussion}

\subsection{Analysis of Percentage Statistics}

Overall, the development of professional identity before nursing students' internship is not ideal. Only about half of the nursing students (52.2\%) are in the type of career achievement, that is, the most ideal state. These nursing students have clear career goals and will work hard to achieve the target career. There are 
Table 3. LSD multiple comparison analysis results in different admission levels.

\begin{tabular}{|c|c|c|c|c|c|}
\hline $\begin{array}{l}\text { Dependent } \\
\text { variable }\end{array}$ & $\begin{array}{c}\text { (I) Admission } \\
\text { level }\end{array}$ & $\begin{array}{c}\text { (J) Admission } \\
\text { level }\end{array}$ & $\begin{array}{c}\text { Mean } \\
\text { difference }(\mathrm{I})-(\mathrm{J})\end{array}$ & $\begin{array}{c}\text { Standard } \\
\text { error }\end{array}$ & $p$ \\
\hline \multirow{6}{*}{$\begin{array}{c}\text { Career } \\
\text { achievement }\end{array}$} & The first batch & $\begin{array}{c}\text { From senior } \\
\text { college }\end{array}$ & -0.683 & 0.335 & 0.043 \\
\hline & & $\begin{array}{c}\text { The second } \\
\text { batch }\end{array}$ & -1.458 & 0.284 & 0.000 \\
\hline & $\begin{array}{l}\text { From senior } \\
\text { college }\end{array}$ & The first batch & 0.683 & 0.335 & 0.043 \\
\hline & \multirow{3}{*}{$\begin{array}{c}\text { The second } \\
\text { batch }\end{array}$} & $\begin{array}{c}\text { The second } \\
\text { batch }\end{array}$ & -0.776 & 0.332 & 0.021 \\
\hline & & The first batch & 1.458 & 0.284 & 0.000 \\
\hline & & $\begin{array}{l}\text { From senior } \\
\text { college }\end{array}$ & 0.776 & 0.332 & 0.021 \\
\hline
\end{tabular}

very few nursing students in the type of career foreclosure, the type of student also has a clear career goal, but the goal is formed by the influence of others, not the result of their own deliberations. About one-third (35.5\%) of nursing students are in the type of career moratorium, although they have not formed a stable career goal, they are actively exploring, still can be called a positive state. There are very few nursing students in the type of career diffusion. And the type of almost $10 \%$ of the nursing students is ambiguous. This result is better than ordinary university students, the survey targeted at ordinary college students in china showed that less than one-fifth of students are in career-achievement status. Perhaps the career goal of a small number of nursing students with career achievement type or foreclosure is not a nurse, but at least they already have a clear goal, and they will work hard for it, which is also worth encouraging. One study showed (Mancini, Caricati, Panari et al., 2015) that the students with achievement or foreclosure identities had higher scores on measures of academic self-esteem and intrinsic work value. The nursing students with career moratorium type are actively exploring career directions, so educators should seize the opportunity to give guidance. A small number of nursing student with career diffusion, career foreclosure, or unclear development type should be guided and educated as much as possible to actively enter the state of nurses' career achievement. Although university education now pays more and more attention to general education, students' future careers may not correspond to the majors they are studying, but professional knowledge and skills are the advantages of each college student. In the recruitment process, the employer's first consideration is the major that the student learns. Therefore, nursing students should be guided to take nurses as their future career choice. Otherwise, if the profession he/she is engaged in does not conform to his/her own major, he/she will have to "make up for lessons" in his/her work, adding a lot of burden to his/her work and life, and 
it is also extremely unfavorable to his/her personal career development.

\subsection{Analysis of Comparison Results of Professional Identity among Different Categories of Nursing Students}

The comparison of professional identity status of three categories of nursing students before their internship shows that only the difference in the career achievement dimension is statistically significant, the second batch of undergraduate nursing students admitted have the highest score, followed by the undergraduate nursing students admitted from junior colleges, the first batch of undergraduate nursing student admitted have the lowest score. There may be three reasons: 1) The second batch of undergraduate students' entrance examination score is relatively low, so they have more stable professional thinking and higher recognition of major. 2) The undergraduate nursing students admitted from junior college have undergone junior college internships, they have a better understanding of nurse work, have a clear plan for their future career, and cherish the hard-won opportunity to upgrade their academic qualifications. Willing to further study in nursing major and recognize nursing profession. 3) When enrolling the first batch of undergraduate nursing students in our school, the first voluntary registration rate in the past six years was less than $10 \%$, and most of them were transferred to the nursing major. Therefore, most of them are not interested in nursing major.

The result of this study reminds us that in order to cultivate undergraduate nursing talents who have stable professional thinking and identify nursing majors, we can increase the number of students enrolled in the second batch and junior college graduates, and reduce the number of students enrolled in the first batch.

\subsection{Measures for Improving Nursing Students' Professional Identity}

Professional identity is a state, its formation is a gradual development process. One scholar thinks (Baldwin, Mills, Birks et al., 2017) that role modeling by experienced nurses, including nurse academics, is a key factor in the process of preparing undergraduate nursing students for practice. And found that in order for nurse academics to role model professional behaviors for nursing students, they must reconcile their own professional identity. The results of this study emphasize the important role models in the development of nursing student' professional identity. Therefore, in the process of studying at school, it is best to allow students to keep in touch with clinical nursing practice and excellent clinical teaching teachers. Another study (Chrisman-Khawam \& Manzi, 2020) believes that structured service learning experiences provide students with an opportunity to develop an empathetic professional identity in the preclinical stage of medical education. This form of volunteer is a transformative experience that challenges students' incoming perceptions and leads to the development of both empathy and professional identity. Therefore, while nursing students are study- 
ing at school, teachers can organize them to volunteer services in hospitals, such as "helping patients get medicine", "accompany patients to check", "carry out voluntary counseling", "give warmth and love to patients", etc. Hospital volunteer service is also a form of learning through services. There is also a study (Wu, Palmer, \& Sha, 2020) targeting college nursing students prove that a clinical learning experience that is longer than eight months and a positive perception of the clinical learning environment are the dominant factors positively associated with professional identity. There, it is necessary to create a good internship environment for nursing students in the future internship process, such as harmonious teacher-student relationship, doctor-patient relationship, and high-quality clinical teaching teachers.

\section{Conclusion}

Nearly half of the undergraduate nursing students do not explicitly set nurses as their future career goals before the clinical internship, so the development status of professional identity is generally not optimistic. Among them, the second batch of admissions from senior middle school have the highest degree of career achievement, the first batch admissions have the lowest, and the admissions from junior college graduates are in the middle. In view of the situation, it is necessary to establish guidance paths and measures for the development of professional identity of undergraduate nursing students at different admission levels, so that students' professional identity becomes career achievement type. If so, students will determine the professional nurses as their own career goals, and devote all their body and soul to the clinical internship process. This will further promote the quality of clinical internships and improve the quality of nursing personnel training, so that after graduation nursing students can become better clinical nurses, make greater contributions to the human health.

\section{Conflicts of Interest}

The authors declare no conflicts of interest regarding the publication of this paper.

\section{References}

Baldwin, A., Mills, J., Birks, M. et al. (2017). Reconciling Professional Identity: A Grounded Theory of Nurse Academic' Role Modelling for Undergraduate Students. Nurse Education Today, 59, 1-5. https://doi.org/10.1016/j.nedt.2017.08.010

Browne, C., Wall, P., Batt, S., \& Bennett, R. (2018). Understanding Perceptions of Nursing Professional Identity in Students Entering an Australian Undergraduate Nursing Degree. Nurse Education in Practice, 32, 90-96.

https://doi.org/10.1016/j.nepr.2018.07.006

Chrisman-Khawam, L. M., \& Manzi, J. A. (2020). Empathy in Medicine Cultivating an Empathetic Professional Identity in Osteopathic Medical Students through Service Learning: A Qualitative Analysis of Reflective Essays. Journal of Osteopathic Medicine, 120, 263-272. https://doi.org/10.7556/jaoa.2020.043

Green, J. L. (2018). Peer Support Systems and Professional Identity of Student Nurses 
Undertaking a UK Learning Disability Nursing Programme. Nurse Education in Practice, 30, 56-61. https://doi.org/10.1016/j.nepr.2017.11.009

Mancini, T., Caricati, L., Panari, C. et al. (2015). Personal and Social Aspects of Professional Identity: An Extension of Marcia's Identity Status Model Applied to a Sample of University Students. Journal of Vocational Behavior, 89, 140-150. https://doi.org/10.1016/j.jvb.2015.06.002

Melgosa, J. (1987). Development and Validation of the Occupational Identity Scale. Journal of Adolescence, 10, 385-397. https://doi.org/10.1016/S0140-1971(87)80019-2

Sternszus, R., Boudreau, J. D., Cruess, R. L. et al. (2020). Clinical Teachers' Perceptions of Their Role in Professional Identity Formation. Academic Medicine, 95, 1594-1599. https://doi.org/10.1097/ACM.0000000000003369

Wu, C., Palmer, M. H., \& Sha, K. H. (2020). Professional Identity and Its Influencing Factors of First-Year Post-Associate Degree Baccalaureate Nursing Students: A CrossSectional Study. Nurse Education Today, 84, Article ID: 104227.

https://doi.org/10.1016/j.nedt.2019.104227 